\title{
Percutaneous Coronary Intervention by Radial Approach: Technique Incorporation and Outcomes at an Interventional Cardiology Training Center
}

\author{
Gentil Barreira de Aguiar Filho', Dimytri A. Siqueira², Áurea J. Chaves ${ }^{3}$, Felipe M. Coelho', J. Ribamar \\ Costa Junior ${ }^{5}$, Mateus Veloso ${ }^{6}$, Louis N. Ohe ${ }^{7}$, Ricardo A. Costa ${ }^{8}$, Daniel Chamié ${ }^{9}$, Rodolfo Staico ${ }^{10}$, \\ Sergio Braga ${ }^{11}$, Fausto Feres ${ }^{12}$, Alexandr Abizaid ${ }^{13}$, Amanda G. M. R. Sousa $^{14}$, J. Eduardo Sousa ${ }^{15}$
}

\begin{abstract}
Background: The radial artery access has evolved into a flexible approach in the last decade, showing similar or superior results when compared to the femoral approach. We assessed the incorporation of the radial artery access in a training center for interventional cardiologists and compared the results to those of the femoral artery access. Methods: Observational, single-center study, including consecutive patients undergoing percutaneous coronary intervention (PCI) between 2007 and 2011. The access route was chosen by the resident along with the interventionist responsible for $\mathrm{PCl}$. We compared the composite endpoint of death, periprocedural myocardial infarction (MI), ischemic stroke or major bleeding between the two groups during hospitalization. Results: Among 5,545 patients undergoing $\mathrm{PCl}, 29.8 \%$ used the radial approach and 70.2 used the femoral approach. Mean age was $60.8 \pm$ 11.7 years, $68.9 \%$ were males and $29 \%$ had acute coronary syndromes. There was an increase in the use of the radial approach until 2010 and stabilization in the subsequent year $(11.8 \%$ in $2008,26.2 \%$ in $2009,45.1 \%$ in 2010 and $42.6 \%$ in 2011). Patients using the radial approach had a less complex clinical and angiographic profile. There were no differences in the composite endpoint ( $5 \%$ vs. $5.9 \%$; $\mathrm{P}=0.18$ ), death
\end{abstract}

\section{RESUMO}

Intervenção Coronária Percutânea pela Via Radial: Incorporação da Técnica e Resultados de um Centro de Formação em Cardiologia Intervencionista

Introdução: A via radial evoluiu na última década para uma abordagem versátil, mostrando resultados equivalentes ou superiores aos da via femoral. Avaliamos a incorporação da técnica radial em um centro formador de cardiologistas intervencionistas, e comparamos seus resultados aos da técnica femoral. Métodos: Estudo observacional, unicêntrico, que incluiu pacientes consecutivos submetidos a intervenção coronária percutânea (ICP) entre 2007 e 2011. A via de acesso foi escolhida pelo residente, em conjunto com o intervencionista responsável pela ICP. Comparamos o desfecho combinado de óbito, infarto do miocárdio (IM) periprocedimento, acidente vascular cerebral isquêmico ou sangramentos maiores entre os dois grupos na fase hospitalar. Resultados: Foram submetidos a ICP 5.545 pacientes, $29,8 \%$ pela via radial e $70,2 \%$ pela via femoral. A média de idade foi de $60,8 \pm 11,7$ anos, sendo $68,9 \%$ do sexo masculino e $29 \%$ portadores de síndromes coronárias agudas. Houve aumento do uso da via radial até 2010, e estabilização no ano subsequente $(11,8 \%$ em 2008, 26,1\% em 2009, 45,1\%

\footnotetext{
1 Resident Physician at the Invasive Cardiologist Service of Instituto Dante Pazzanese de Cardiologia. São Paulo, SP, Brazil.

2 Doctor. Interventionist Cardiologist Physician at the Invasive Cardiologist Service of Instituto Dante Pazzanese de Cardiologia. São Paulo, SP, Brazil.

${ }^{3}$ Doctor. Cardiologist Physician at the Invasive Cadiology Service of Instituto Dante Pazzanese de Cardiologia. São Paulo, SP, Brazil.

${ }^{4}$ Resident Physician at the Invasive Cardiologist Service of Instituto Dante Pazzanese de Cardiologia. São Paulo, SP, Brazil.

${ }^{5}$ Doctor. Interventionist Cardiologist Physician at the Invasive Cardiology Service of Instituto Dante Pazzanese de Cardiologia. São Paulo, SP, Brazil.

${ }^{6}$ Resident physician of the Invasive Cardiologist Service at Instituto Dante Pazzanese de Cardiologia. São Paulo, SP, Brazil.

7 Resident Physician at the Invasive Cardiologist Service of Instituto Dante Pazzanese de Cardiologia. São Paulo, SP, Brazil.

${ }^{8}$ Doctor. Interventionist Cardiologist Physician at the Invasive Cardiology Service of Instituto Dante Pazzanese de Cardiologia. São Paulo, SP, Brazil.

${ }^{9}$ Interventionist Cardiologist Physician at the Invasive Cardiology Service of Instituto Dante Pazzanese de Cardiologia. São Paulo, SP, Brazil.
}

\begin{abstract}
10 Doctor. Interventionist Cardiologist at the Invasive Cardiology Service of Instituto Dante Pazzanese de Cardiologia. São Paulo, SP, Brazil.

${ }^{11}$ Doctor. Head of the Hemodynamics Section of Instituto Dante Pazzanese de Cardiologia. São Paulo, SP, Brazil.

12 Doctor. Interventionist Cardiologist Physician at the Invasive Cardiology Service of Instituto Dante Pazzanese de Cardiologia. São Paulo, SP, Brazil.

${ }^{13}$ Full Professor. Director of the Invasive Cardiology Service of Instituto Dante Pazzanese de Cardiologia. São Paulo, SP, Brazil.

${ }_{14}$ Full Professor. CEO of Instituto Dante Pazzanese de Cardiologia. São Paulo, SP, Brazil.

15 Full Professor. Director of the Heart Structural Diseases Interventions Center of Instituto Dante Pazzanese de Cardiologia. São Paulo, SP, Brazil
\end{abstract}

Correspondence to: Gentil Barreira de Aguiar Filho. Rua Borges Lagoa, 1.209 - Vila Clementino - São Paulo, SP, Brazil - CEP 04038-033

E-mail: gentilbarreira@gmail.com

Received on: 9/26/2012 • Accepted on: 12/3/2012 
( $0.1 \%$ vs. $0.8 \% ; \mathrm{P}=0.71)$, stroke $(0.06 \%$ vs. $0.03 \% ; \mathrm{P}=0.53)$ or periprocedural $\mathrm{MI}(4.5 \%$ vs. $3.8 \% ; \mathrm{P}=0.27)$. However, there was a lower incidence of major bleeding events $(0.4 \%$ vs. $1.3 \% ; \mathrm{P}<0.01)$ and vascular complications $(0.5 \%$ vs. $2.2 \% ; \mathrm{P}<0.01)$ with the radial approach. Conclusions: At our interventional cardiology training center, $\mathrm{PCl}$ through the radial approach was quickly incorporated and provided, for selected patients, outcomes similar to those of the femoral approach, with decrease of major bleeding and vascular complication rates.

DESCRIPTORS: Angioplasty. Stents. Radial artery. Femoral artery. Hemorrhage.

$\mathrm{T}$ raditionally, percutaneous coronary intervention (PCI) is performed via the femoral artery. This approach has well-defined anatomical and radiological landmarks, and the technique is broadly used by interventional cardiologists. ${ }^{1}$ The radial approach, in use for over two decades, has developed into a versatile method for cardiac catheterization as well as for $\mathrm{PCI}$, with equivalent or even superior clinical results to those of the femoral approach. ${ }^{2-6}$

The advantages of the radial approach include lower rates of bleeding and vascular complications, ${ }^{2-4}$ in addition to lower mortality rates in certain patient subgroups. ${ }^{2,5}$ The success rate is similar to that of the femoral approach, ${ }^{4,6}$ particularly in experienced hands. Thus, learning to perform this approach is fundamental in the training of interventional cardiology specialists.

The present study aimed to evaluate the incorporation of the radial approach over the past several years at this institution, and to compare its results with those of the femoral technique.

\section{METHODS}

\section{Study design}

This observational, single-center study included consecutive patients undergoing $\mathrm{PCl}$ from December 2007 to November 2011. The approach was selected by the resident physician of the interventional cardiology service together with the supervising interventional cardiologist, after a subjective evaluation of the radial pulse, complemented by the objective evaluation of the Allen test.

Percutaneous procedures were performed according to current guidelines. ${ }^{1}$ Data from hospital outcomes were collected during the hospitalization using standard forms. Data collected included clinical, angiographic, and procedural characteristics, as well as the clinical course until the time of hospital discharge. em 2010 e 42,6\% em 2011). Os pacientes que utilizaram a via radial tinham perfil tanto clínico como angiográfico menos complexo. Não houve diferenças nos desfechos combina dos $(5 \%$ vs. $5,9 \%$; $P=0,18)$, no óbito $(0,1 \%$ vs. $0,8 \%$; $P=0,71)$, no acidente vascular cerebral $(0,06 \%$ vs. $0,03 \%$ $\mathrm{P}=0,53)$ ou no IM periprocedimento $(4,5 \%$ vs. $3,8 \%$; $\mathrm{P}=0,27)$. Contudo, menor incidência de sangramentos maiores $(0,4 \%$ vs. $1,3 \% ; P<0,01)$ e de complicações vasculares $(0,5 \%$ vs. $2,2 \% ; P<0,01)$ foi observada com a via radial. Conclusões: Em nosso centro formador de cardiologistas intervencionistas, a ICP pela via radial foi rapidamente incorporada, e trouxe, para pacientes selecionados, resultados equivalentes aos da via femoral, com redução dos índices de sangramentos maio res e de complicações vasculares.

DESCRITORES: Angioplastia. Stents. Artéria radial. Artéria femoral. Hemorragia.

\section{Procedure}

The radial puncture was performed using the Seldinger technique, preferably on the right side. The puncture was made $1 \mathrm{~cm}$ proximal to the styloid process of the radius, using a tapered, hydrophilic Glidesheath introducer (Terumo Medical - Tokyo, Japan) specifically made for accessing the radial artery. Heparin was administered at a dose of 5,000 IU through the introducer, and its dose increased to 70 to $100 \mathrm{IU} /$ $\mathrm{kg}$. Immediately following the procedure, the sheath was removed and hemostasis was achieved using the TR Band ${ }^{\mathrm{TM}}$ device (Terumo Medical - Tokyo, Japan) to compress the radial artery.

The femoral artery puncture was performed according to the standard Judkins technique, preferably on the right side, using $6 \mathrm{~F}$ or $7 \mathrm{~F}$ introducers. Heparin was administered at a dose of 2,500 IU and increased to 70 to $100 \mathrm{lU} / \mathrm{kg}$. The introducer was removed approximately two hours after the procedure, and haemostasis was achieved by manual compression.

\section{Definitions and in-hospital follow-up}

The composite endpoint of in-hospital death, periprocedural myocardial infarction (MI), ischemic stroke, or major bleeding was compared between the two groups. The individual components of the composite outcome and the incidence of vascular complications were also compared.

As a rule, all deaths were considered cardiac unless a noncardiac cause could be clearly established by clinical and/or pathological assessment. Periprocedural MI was defined as the presence of new Q waves in two or more contiguous leads or an elevation of the creatine kinase $M B$ fraction $(C K-M B)$ at least three times above the normal upper limit.

Major bleeding was defined as a hemorrhagic stroke, or any bleeding that caused hemodynamic changes and required treatment. Vascular complications 
included hematomas greater than $5 \mathrm{~cm}$, pseudoaneurysms, arteriovenous fistulas, or bleeding episodes requiring transfusion or surgery. Angiographic success was defined as attaining a final Thrombolysis in Myocardial Infarction (TIMI) 3 flow with no dissection and with the residual stenosis $<20 \%$.

\section{Statistical analysis}

SPSS for Windows was used for statistical analysis. Categorical variables were described as frequencies and percentages and compared using the chi-squared or Fisher's exact test, as appropriate. Continuous variables were calculated as the means and standard deviations, and were compared using Student's t-test. All tests were two-tailed, and a P-value $<0.05$ was considered statistically significant.

\section{RESULTS}

From December 2007 to November 2011, 5,545 consecutive patients underwent $\mathrm{PCl}, 1,652$ (29.8\%) via the radial approach and $3,893(70.2 \%)$ via the femoral approach. The mean age in the study population was $60.8 \pm 11.7$ years; $68.9 \%$ were males, $30 \%$ were diabetics, and $29 \%$ had acute coronary syndromes (11.4\% with STEMI).

There was a progressive increase in the use of the radial approach until 2010, stabilizing in 2011 (11.8\% in $2008,26.1 \%$ in $2009,45.1 \%$ in 2010 , and $42.6 \%$ in 2011) (Figure 1). The net overall increase in the proportion of $\mathrm{PCl}$ completed using the radial technique was $30.8 \%(P<0.01)$.

The patients who underwent the radial approach tended to have a less complex clinical profile. They were younger $(59.8 \pm 11.6$ years vs. $61.3 \pm 11.7$ years; $P<0.01)$, more often males $(76.4 \%$ vs. $65.8 \%$; $\mathrm{P}<0.01)$, less likely to have had a prior MI $(39 \%$ vs. $42.2 \%$; $P=0.02$ ), less likely to have had a prior myocardial revascularization operation $(5.8 \%$ vs. $11.9 \%$;

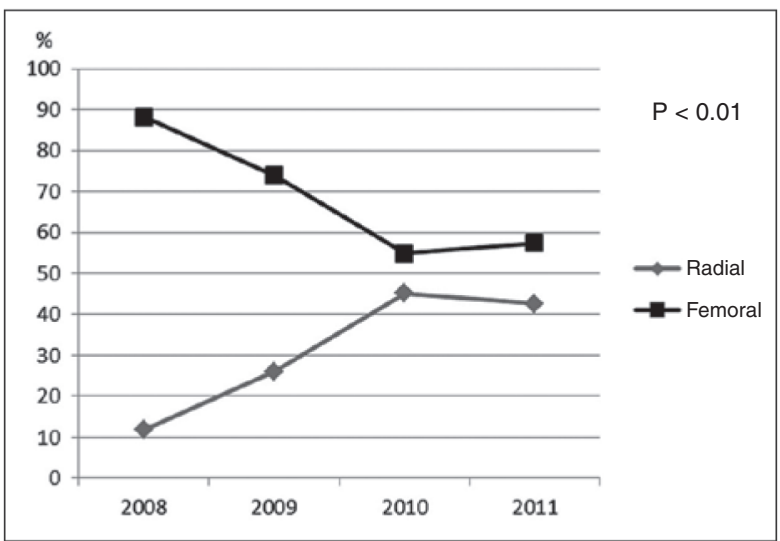

Figure 1 - Evolution of the use of the radial technique.
$\mathrm{P}<0.01)$, and less likely to have chronic renal failure (23\% vs. $29.8 \%$; $P<0.01$ ) (Table 1 ).

In terms of angiographic and procedural characteristics (Table 2), patients accessed via the radial approach had fewer vessels treated $(1.14 \pm 0.38$ vs. $1.19 \pm 0.42$; $\mathrm{P}<0.01)$, less frequent use of pre- $(43 \%$ vs. $55 \%$; $\mathrm{P}<0.01)$, and post-dilation $(74 \%$ vs. $77 \% ; \mathrm{P}=0.01)$, less frequent use of distal protection filters $(0.3 \%$ vs. $1 \% ; P=0.01)$, less contrast used $(85.8 \mathrm{~mL}$ vs. $39.5+$ $97.3+48.1 \mathrm{~mL} ; \mathrm{P}<0.01)$, and less frequent ad hoc procedures $(12.5 \%$ vs. $17.3 \% ; \mathrm{P}<0.01)$. The rate of angiographic success was $94.8 \%$ in the radial group, and $94 \%$ in the femoral group $(P=0.33)$.

When analyzing hospital adverse events, there were no differences in rates of the composite endpoint $(5 \%$ vs. $5.9 \% ; P=0.18)$, death $(0.1 \%$ vs. $0.8 \% ; P=0.71)$, stroke $(0.06 \%$ vs. $0.03 \%$; $P=0.53)$, or periprocedural MI $(4.5 \%$ vs. $3.8 \%$; $P=0.27)$. However, lower incidences of major bleeding $(0.4 \%$ vs. $1.3 \%$; $P<0.01)$ and vascular complications $(0.5 \%$ vs. $2.2 \%$; $\mathrm{P}<0.01)$ were observed in patients undergoing $\mathrm{PCl}$ via the radial approach (Table 3).

In terms of more severe vascular complications, there were four $(0.1 \%)$ cases of retroperitoneal hemorrhage and three $(0.7 \%)$ arteriovenous fistulas in the femoral group.

\section{DISCUSSION}

This study demonstrated a significant increase in the use of the radial approach during the period of 2008 to 2010, with subsequent stabilization. This approach is currently responsible for almost half of all PCls performed at this institution, which is a training center for interventional cardiologists. In one of the few publications that addressed this topic in Brazil, Andrade et al., ${ }^{7}$ using data from National Center of Cardiovascular Interventions (Central Nacional de Intervenção Cardiovascular - CENIC), demonstrated an underutilization of the radial access in all of Brazil before $2008(12.7 \%$ in 2005, $14.9 \%$ in 2006, $11.2 \%$ in 2007, and $14 \%$ in 2008).

The present study also revealed reduced incidences of bleeding and vascular complications, paralleling a series of recently published studies..$^{2-4}$ Review of major bleeding after $\mathrm{PCl}$ has become increasingly important, as the occurrence of such events related to the puncture site is directly associated with increased morbidity and mortality, ${ }^{8-11}$ in addition to reduced adherence to antiplatelet therapy, an important predictor of stent thrombosis. ${ }^{12}$ A reduction of bleeding along the access route brings even greater benefits to high-risk subgroups, such as elderly patients, ${ }^{3,13}$ females, $^{3}$ or those with acute coronary syndrome. ${ }^{14}$

Specifically, in the treatment of acute coronary syndrome with and without ST-segment elevation, 
Table 1

Baseline clinical characteristics

\begin{tabular}{|c|c|c|c|}
\hline & $\begin{array}{c}\text { Radial } \\
\mathrm{n}=1,1652\end{array}$ & $\begin{array}{c}\text { Femoral } \\
\mathbf{n}=3,893\end{array}$ & $\mathbf{P}$ \\
\hline Mean age, years & $59.8 \pm 11.6$ & $61.3 \pm 11.7$ & $<0.01$ \\
\hline Male gender, n (\%) & $1,262(76.4)$ & $2,561(65.8)$ & $<0.01$ \\
\hline Arterial hypertension, $\mathrm{n}(\%)$ & $1,406(85.1)$ & $3,320(85.3)$ & 0.86 \\
\hline Dyslipidemia, n (\%) & $1,104(66.8)$ & $2,607(67)$ & 0.92 \\
\hline Diabetes mellitus, n (\%) & $492(29.8)$ & $1,197(30.7)$ & 0.47 \\
\hline Smoking, n (\%) & $335(20.2)$ & $752(19.3)$ & 0.41 \\
\hline Previous coronary artery bypasses graft surgery, n (\%) & $95(5.8)$ & $465(11.9)$ & $<0.01$ \\
\hline Previous myocardial infarction, n (\%) & $644(39)$ & $1,644(42.2)$ & 0.02 \\
\hline Peripheral vascular disease, $\mathrm{n}(\%)$ & $49(3)$ & $75(1.9)$ & 0.04 \\
\hline Chronic renal failure, n (\%) & $380(23)$ & $1,162(29.8)$ & $<0.01$ \\
\hline
\end{tabular}

Table 2

Angiographic and procedural characteristics

\begin{tabular}{|c|c|c|c|}
\hline & $\begin{array}{c}\text { Radial } \\
n=1,1652\end{array}$ & $\begin{array}{c}\text { Femoral } \\
n=3,893\end{array}$ & $\mathbf{P}$ \\
\hline Treated vessel, n (\%) & & & $<0.01$ \\
\hline RCA & $534(32.3)$ & $1,300(33.4)$ & \\
\hline $\mathrm{Cx}$ & $311(18.8)$ & $685(17.6)$ & \\
\hline ADA & $654(39.6)$ & $1,347(34.6)$ & \\
\hline LMCA & $10(0.6)$ & $58(1.5)$ & \\
\hline Mean treated vessels & $1.14 \pm 0.38$ & $1.19 \pm 0.42$ & $<0.01$ \\
\hline Pre-dilation, n (\%) & $710(43)$ & $2,141(55)$ & $<0.01$ \\
\hline Post-dilation, n (\%) & $1,222(74)$ & $2,988(77)$ & 0.01 \\
\hline Use of abciximab, n (\%) & $31(1.9)$ & $43(1.1)$ & 0.04 \\
\hline Use of tirofiban, $\mathrm{n}(\%)$ & $59(3.6)$ & $175(4.5)$ & 0.29 \\
\hline Thrombus aspiration, $\mathrm{n}(\%)$ & $7(0.42)$ & $8(0.2)$ & 0.37 \\
\hline Distal protection filter, n (\%) & $5(0.3)$ & $39(1)$ & 0.01 \\
\hline Stent with strut overlap, n (\%) & $165(10)$ & $455(11.7)$ & 0.08 \\
\hline Ad hoc procedure, n (\%) & $207(12.5)$ & $673(17.3)$ & $<0.01$ \\
\hline Complete revascularization, $\mathrm{n}(\%)$ & $75(4.5)$ & $72(1.8)$ & 0.05 \\
\hline Angiographic success, n (\%) & $1,566(94.8)$ & $3,660(94)$ & 0.33 \\
\hline
\end{tabular}

RCA, right coronary artery; Cx, circumflex; ADA, anterior descending artery; LMCA, left main coronary artery

Romagnoli et al. ${ }^{5}$ demonstrated that the use of radial access reduced the 30-day cardiovascular mortality rate, the incidence of bleeding, and the length of hospital stay. Similar findings were published in a meta-analysis including 21 studies and 8,534 patients. ${ }^{15}$ The analysis of the same population in the Radlal Vs. femorAL access for coronary intervention (RIVAL) study also demonstrated a mortality benefit, but this finding was limited to the subgroup with ST-segment elevation. ${ }^{2}$

In this study, as in previous studies, vascular complications of the radial approach are uncommon and consist predominantly of radial artery occlusion. ${ }^{16}$ This approach rarely results in forearm hematoma, perforation, or compartment syndrome. ${ }^{17,18}$ In experienced groups, 
Table 3

In-hospital complications

\begin{tabular}{lccc}
\hline & Radial & Femoral & \\
& $\mathbf{n = 1 , 1 6 5 2}$ & $\mathbf{n = 3 , 8 9 3}$ & $\mathbf{P}$ \\
\hline Composite outcomes, $\mathrm{n}(\%)$ & $83(5)$ & $231(5.9)$ & 0.18 \\
Mortality, n (\%) & $2(0.1)$ & $30(0.8)$ & 0.71 \\
Stroke, $\mathrm{n}(\%)$ & $1(0.06)$ & $1(0.03)$ & 0.53 \\
Periprocedural myocardial infarction, $\mathrm{n}(\%)$ & $74(4.5)$ & $149(3.8)$ & 0.27 \\
Major bleeding, $\mathrm{n}(\%)$ & $6(0.4)$ & $51(1.3)$ & $<0.01$ \\
Vascular complications, $\mathrm{n}(\%)$ & $8(0.5)$ & $86(2.2)$ & $<0.01$ \\
\hline
\end{tabular}

the rate of vascular complications is small $(0.5 \%)$, a similar rate to that in the present population. The need for an access route change decreases as a surgeon's experience increases. ${ }^{19}$

Surgeon experience is a major determinant in the success rate of $\mathrm{PCl}$ via the radial approach. Louvard et al. ${ }^{20}$ reported technical failure of $10 \%$ in the first 50 cases. This rate drops to $1 \%$ after 1,000 cases; these authors estimate that the learning curve plateaus at 800 cases. The experience of Spaulding et al. ${ }^{21}$ with 415 cases is also instructive: technical failure occurred in $14 \%$ of the first 80 procedures versus in $2 \%$ of the last 100 cases. Looi et al. ${ }^{22}$ describe how, in one year, less experienced surgeons can achieve the same level as their more experienced colleagues, as long as they routinely use the radial approach.

Ball et al. ${ }^{23}$ demonstrated a $32 \%$ decrease in the incidence of technical failure for every $50 \mathrm{PCls}$ performed via the radial approach. There were similar reductions in contrast use, in the number of guidewires used, and in the cumulative fluoroscopy time.

In Brazil, Cardoso et al. ${ }^{24}$ demonstrated that procedures performed by more experienced surgeons ( $>500$ procedures via the radial approach) were completed with shorter puncture, fluoroscopy, and total procedure times, without a change in the rate of complications.

\section{Study limitations}

This observational study has all the limitations inherent to its study design. It was performed in a single training center and without late clinical follow-up. The crossover rates were not evaluated, nor were the duration of the puncture, the number of guidewires used, and the duration of fluoroscopy.

\section{CONCLUSIONS}

In our experience at a training center for interventional cardiologists, $\mathrm{PCl}$ through the radial approach was quickly incorporated; it demonstrated results that were equivalent to those of the femoral approach, with reduced rates of major bleeding and vascular complications in selected patients.

\section{CONFLICT OF INTEREST}

The authors declare no conflicts of interest.

\section{REFERENCES}

1. Levine GN, Bates ER, Blankenship JC, Bailey SR, Bittl JA, Cercek B, et al. 2011 ACCF/AHA/SCAI Guideline for Percutaneous Coronary Intervention: a report of the American College of Cardiology Foundation/American Heart Association Task Force on Practice Guidelines and the Society for Cardiovascular Angiography and Interventions. Circulation. 2011;124(23):e574-651.

2. Jolly SS, Yusuf S, Cairns J, Niemelä K, Xavier D, Widimsky P, et al. Radial versus femoral access for coronary angiography and intervention in patients with acute coronary syndromes (RIVAL): a randomised, parallel group, multicentre trial. Lancet. 2011;377(9775):1409-20.

3. Rao SV, Ou FS, Wang Ty. Trends in the prevalence and outcomes of radial and femoral approaches to percutaneous coronary intervention: a report from the National Cardiovascular Data Registry. JACC Cardiovasc Interv. 2008;1(4):379-86.

4. Jolly SS, Amlani S, Hamon M, Yusuf S, Mehta SR. Radial versus femoral access for coronary angiography or intervention and the impact on major bleeding and ischemic events: a systematic review and meta-analysis of randomized trials. Am Heart J. 2009;157(1):132-40.

5. Romagnoli E, Biondi-Zoccai G, Sciahbasi A, Politi L, Rigattieri S, Pendenza G, et al. Radial versus femoral randomized investigation in ST-Segment Elevation acute coronary syndrome: the RIFLE-STEACS (Radial Versus Femoral Randomized Investigation in ST-Elevation Acute Coronary Syndrome) Study. J Am Coll Cardiol. 2012;60(24):2481-9.

6. Godinho RR, Ribeiro HB, Faig S, Spadaro AG, Gabrilaitis C, Sacramento G, et al. Comparação das vias radial e femora nas intervenções coronárias percutâneas: resultados do Registro TotalCor. Rev Bras Cardiol Invasiva. 2011;19(3):272-8.

7. Andrade PB, Tebet MA, Andrade MV, Labrunie A, Mattos LA. Radial approach in percutaneous coronary interventions: current status in Brazil. Arq Bras Cardiol. 2011;96(4):312-6.

8. Doyle BJ, Rihal CS, Gastineau DA, Holmes DR Jr. Bleeding, blood transfusion, and increased mortality after percutaneous coronary intervention: implications for contemporary practice. J Am Coll Cardiol. 2009;53(22):2019-27. 
9. Rao SV, Eikelboom JA, Granger CB, Harrington RA, Califf RM, Bassand JP. Bleeding and blood transfusion issues in patients with non-ST-segment elevation acute coronary syndromes. Eur Heart J. 2007;28(10):1193-204

10. Kugelmass AD, Cohen DJ, Brown PP, Simon AW, Becker ER, Culler SD. Hospital resources consumed in treating complications associated with percutaneous coronary interventions. Am J Cardiol. 2006;97(3):322-7.

11. Kinnaird TD, Stabile E, Mintz GS, Lee CW, Canos DA, Gevorkian N, et al. Incidence, predictors, and prognostic implications of bleeding and blood transfusion following percutaneous coronary interventions. Am J Cardiol. 2003;92(8): 930-5.

12. Mehran R, Rao SV, Bhatt DL, Gibson CM, Caixeta A, Eikelboom J, et al. Standardized bleeding definitions for cardiovascular clinical trials: a consensus report from the Bleeding Academic Research Consortium. Circulation. 2011;123(23):2736-47.

13. Andrade PB, Tebet MA, Andrade MVA, Barbosa RA, Mattos LA, Labrunie A. Impacto da utilização do acesso radial na ocorrência de sangramento grave entre idosos submetidos a intervenção coronária percutânea. Rev Bras Cardiol Invasiva. 2012;20(1):16-20.

14. Généreux P, Mehran R, Palmerini T, Caixeta A, Kirtane AJ, Lansky AJ, et al. Radial access in patients with ST-segment elevation myocardial infarction undergoing primary angioplasty in acute myocardial infarction: the HORIZONS-AMI trial. Eurolntervention. 2011;7(8):905-16.

15. Mehta SR, Jolly SS, Cairns J, Niemela K, Rao SV, Cheema AN, et al. Effects of radial versus femoral artery access in patients with acute coronary syndromes with or without ST-Segment Elevation. J Am Coll Cardiol. 2012;60(24):2490-9.
16. Stella PR, Kiemeneij F, Laarman GJ, Odekerken D, Slagboom T, van der Wieken R. Incidence and outcome of radial artery occlusion following transradial artery coronary angioplasty. Cathet Cardiovasc Diagn. 1997;40(2):156-8.

17. Calviño-Santos RA, Vázquez-Rodríguez JM, Salgado-Fernández J, Vázquez-González N, Pérez-Fernández R, Vázquez-Rey E, et al. Management of iatrogenic radial artery perforation. Catheter Cardiovasc Interv. 2004;61(1):74-8.

18. Tizón-Marcos H, Barbeau GR. Incidence of compartment syndrome of the arm in a large series of transradial approach for coronary procedures. J Interv Cardiol. 2008;21(5):380-4.

19. Burzotta F, Trani C, Mazzari MA, Tommasino A, Niccoli G, Porto I, et al. Vascular complications and access crossover in 10,676 transradial percutaneous coronary procedures. Am Heart J. 2012;163(2):230-8.

20. Louvard $Y$, Benamer H, Garot P, Hildick-Smith D, Loubeyre C, Rigattieri $\mathrm{S}$, et al. Comparison of transradial and transfemoral approaches for coronary angiography and angioplasty in octogenarians (the OCTOPLUS study). Am J Cardiol. 2004; 94(9):1177-80.

21. Spaulding C, Lefevre T, Funck F, Thebault B, Chauveau M, Ben Hamda K, et al. Left radial approach for coronary angiography: results of a prospective study. Cathet Cardiovasc Diagn. 1996;39(4):365-70.

22. Looi JL, Cave A, El-Jack S. Learning curve in transradial coronary angiography. Am J Cardiol. 2011;108(8):1092-5.

23. Ball WT, Sharieff W, Jolly SS, Hong T, Kutryk MJ, Graham JJ, et al. Characterization of operator learning curve for transradial coronary interventions. Circ Cardiovasc Interv. 2011;4(4):336-41.

24. Cardoso CO, Moraes CV, Voltolini I, Azevedo EM, Santos MA, Borba RP, et al. Influência da curva de aprendizado nos procedimentos percutâneos por via transradial. Rev Bras Cardiol Invasiva. 2011;19(3):260-5. 